\title{
Т.Г. Прохорова
}

\section{«НОВАЯ СЕНТИМЕНТАЛЬНОСТЬ» В РОМАНАХ М. ШИШКИНА «ПИСЬМОВНИК» И Е. ВОДОЛАЗКИНА «АВИАТОР»}

\begin{abstract}
Исследуется феномен «новой сентиментальности», характер функиионирования сентименталистского дискурса в романах М. Шишкина «Письмовник» (2010) и Е. Водолазкина «Авиатор» (2016). В ходе анализа доказано, что диалог с сентиментализмом в произведениях современных авторов осуществляется по закону отрицания отрицания. Выявлена его роль в организации художественной структуры анализируемых романов, в мироощущении героев, в авторской концепщии, определяющей систему иенностей.

Ключевые слова: новая сентиментальность, чувствительность, сенсорность, эпистолярный роман, дневник, сентименталистский дискурс, М. Шишкин, Е. Водолазкин.
\end{abstract}

Термин «неосентиментализм» по отношению к современной русской литературе получил признание прежде всего благодаря работам Н.Л. Лейдермана и М.Н. Эпштейна [1-3]. Первый обнаруживает истоки неосентиментализма уже в советской литературе 1930-х и 1960-1970-х гг., в произведениях А. Афиногенова, К. Паустовского, Р. Фраермана, В. Астафьева [2]. Как считает исследователь, в этот период неосентиментализм представлял хотя и маргинальную, но «живучую» линию литературного процесса. В 1980-1990-е гг. он, по словам Н.Л. Лейдермана, становится уже «заметной и сильной тенденцией» [Там же], которая обнаруживает себя в прозе Л. Улицкой, М. Палей, Н. Горлановой, Г. Щербаковой, С. Василенко, в драматургии Н. Коляды [Там же]. Н.Л. Лейдерман относит неосентиментализм к типу «нетрадиционных» структур диалогической природы, в которой «модель мира, воспринимаемая современным художественным сознанием как архаическая, противостоит тем моделям мира, которые доминируют в современном литературном процессе. В диалоге между ними, с одной стороны, отстаиваются те старомодные ценности, которые были открыты при посредничестве “старого” метода, а с другой - с горькой иронией констатируется несовместимость этих ценностей с современным представлением о действительности, о подлинной мере вещей» [Там же].

М.Н. Эпштейн выстраивает свою концепцию «новой сентиментальности», исходя из анализа постмодернистских произведений - поэмы Вен. Ерофеева «Москва - Петушки» и творчества Тимура Кибирова [3. С. 431447], Обнаружив в них приметы «неосентиментальной эстетики», ученый предложил новый вариант термина для определения подобного рода явлений - «транссентиментальность»: 
«...Последняя треть XX века проходила под знаком “пост”, тем самым завершая и отодвигая в прошлое такие явления и понятия Нового времени (Modernity), как “истина" и “объективность", “душа" и "субъективность” $<\ldots>$ "искренность" и "сентиментальность". На рубеже XX и XXI веков они возрождаются с приставкой “транс"» [3. С. 443].

По определению исследователя, «транссентиментальность - это сентиментальность после смерти сентиментальности, прошедшая через все круги карнавала, иронии и черного юмора, чтобы осознать собственную банальность - и принять ее как неизбежность, как источник нового лиризма» [Там же. С. 433].

В итоге Н.Л. Лейдерман и М.Н. Эпштейн приходят к сходным выводам: каждый из них ищет некую альтернативу постмодернизму и находит её в опыте сентиментализма, подразумевая при этом не повтор того, что уже было освоено культурой, а новый виток её развития. По словам М.Н. Эпштейна, «цитатность со всех сторон объемлет российскую жизнь, как её бесконечная литературность, повторяемость...», соответственно, направление нового витка заключается в «движении от бескавычнобезмятежного слова к закавыченно-ироническому и далее к раскавыченнодерзко-сентиментальному» [Там же. С. 447]. Размышлениями о возможных перспективах развития российской культуры завершается и статья Н.Л. Лейдермана. Ученый задается вопросом, какой будет в новом тысячелетии идея Космоса? Среди предполагаемых моделей он выдвигает и ту, которую можно определить как неосентименталистскую: «это будет Космос, знающий о своей хрупкости, необъективности и условности, Космос, не забывающий о соседстве с Хаосом, не отделяющий себя от Хаоса и ведущий с ним не прекращающийся ни на секунду философский диалог» [2].

Каждый из исследователей сознает, что в литературе XXI в. связь с эпохой сентиментализма по закону прямого наследования традиций невозможна, поэтому диалог с ним осуществляется по закону «отрицания отрицания» или по оксюморонному принципу, позволяющему сочетать несочетаемое. Но видоизменяясь, трансформируясь, «новая сентиментальность» все же сохраняет связь с «первоисточником». Сам по себе интерес к опыту сентиментализма воспринимается сегодня как важный симптом намечающихся в культуре перемен ${ }^{1}$.

В названных работах М.Н. Эпштейна и Н.Л. Лейдермана верхняя хронологическая граница изучаемого материала охватывает 1980-1990-е гг.

${ }^{1}$ Одним из косвенных доказательств особого внимания современной культуры к сфере чувств, индивидуального личностного опыта служит активно развивающаяся в последнее время на Западе и в России новая область исторической науки, возникшая в конце XX в., - история эмоций, занимающаяся разработкой методологий исследования чувств в настоящем и прошлом (см.: [4-6]). В этом плане показательно название статьи Ильи Винницкого, в которой дается обзор этих исследований: «Заговор чувств, или Русская история на «эмоциональном повороте» [7]. Возможно, в нашей истории, действительно, наметился некий «эмоциональный поворот», который и определяет актуализацию сентименталистских тенденций в культуре. 
Между тем проза нулевых и особенно 2010-х гг. представила новые яркие примеры, подтверждающие сделанный учеными прогноз. На наш взгляд, особенно показательны в этом плане романы Михаила Шишкина «Письмовник» (2010) и Евгения Водолазкина «Авиатор» (2015). Тенденция «новой сентиментальности» выражена в них даже более отчетливо, чем в тех произведениях, к которым апеллировали Н.Л. Лейдерман и М.Н. Эпштейн. Но прежде чем приступить к их анализу, необходимо напомнить важнейшие признаки сентиментализма классического, прояснить критерии, которыми мы будем руководствоваться в дальнейшем, уточнить задачи, которые предстоит решить.

M.М. Бахтин отмечал зыбкость и неопределенность границ сентиментализма, который, с одной стороны, «переходит и частично сливается с романтизмом <..>. С другой стороны <..> почти сливается с потоком реализма» [17. С. 304]. И все же ученый утверждал, что, «несмотря на эту зыбкость исторических границ, сентиментализм в своем ядре является совершенно определенным, четким и в высшей степени своеобразным явлением» [9. С. 304]. Современные исследователи часто ссылаются на слова Бахтина, в которых он четко и лаконично сформулировал суть его новаторства: сентиментализм принес с собой «переоценку масштабов», «возвеличение маленького, слабого, близкого», «жизненной детали, мелочи, подробности»; «исповедовал» разочарование в «большой Истории» и обратился к сфере частной, интимной жизни отдельного человека, придал ей «естественное измерение» [Там же]. В центре внимания сентименталистов оказался «внутренний человек и интимные связи между внутренними людьми», а на шкале ценностей главное место заняли «сочувствие, сострадание, жалость. Эмоциональное богатство» [Там же]. Сказанное позволяет говорить не только о сентименталистском направлении, но и о сентиментальности как некоем нравственноэстетическом качестве, которое может проявляться в произведениях разных эпох и разных художественных направлений. С.Г. Бочаров и Л.А. Гоготишвили, авторы комментария к работам Бахтина, подчеркивают, что сентиментализм существовал для него «главным образом не на фоне “борьбы литературных направлений и школ”... но в связи с “... такой проблемой... как “проблема тона в литературе” (ЭСТ, 345), “тональности слова, любого словесного образа (с. 116)” » [Там же. С. 614]. Слово в бахтинской филологии «существует не как нейтральное... а как... проникнутое тоном, смехом и слезами» [Там же]. Намечая план возможных исследований, ученый в своих заметках пишет: «Проследить элементы сентиментализма до наших дней» [Там же. С. 304]. Эта задача сохраняет свою актуальность и сегодня.

В числе ключевых понятий, имеющих принципиальное значение для сентиментализма, традиционно выделим чувствительность. В статье «Что нужно автору?» Н. Карамзин утверждал, что писателю, «если он хочет быть другом и любимцем души нашей», если «хочет писать для вечности», 
нужны не только талант, знания, разум и воображение, но прежде всего «доброе, нежное сердце», воодушевленное «желанием всеобщего блага», сочувствием «всему горестному, всему угнетенному, всему слезящему» [10]. Однако следует учитывать, что понятие «чувствительность / чувствительный» уже в XVIII в. трансформировалось. Это было связано с разочарованием в возможности с его помощью изменить общество, «гармонизировать человеческие отношения». И если до «Сентиментального путешествия...» Л. Стерна корень слова «sentimental» соотносился со значениями «высоконравственный», «разумный» и «назидательный», то уже позже это прежде всего «способный к сочувствию» (см. об этом, в частности: [11. С. 138]). По словам М.В. Кожевникова, «“чувствительники” отошли от общественности в мир своего крошечного “я”, в абстракцию “человечности”, внутренней “свободы”, в уединение, в природу...» [12].

В литературе XXI в. вновь ощущается стремление отойти «от общественности» «в абстракцию “человечности”, внутренней “свободы”». И хотя «новая сентиментальность» вобрала в себя опыт, вынесенный из катастроф XX в., и опыт, усвоенный в эпоху постмодерна, тем не менее она попрежнему выражает способность к со-чувствию, отклик «на все горестное», осознание первостепенной ценности «внутренних связей между людьми». «Новая сентиментальность» диктует и определенную авторскую повествовательную стратегию. Современные исследователи обнаруживают её проявления в произведениях разной эстетической природы. Эпштейн видит присутствие «новой сентиментальности» в творчестве концептуалистов [2. С. 437447], Н.Л. Лейдерман и М.Н. Липовецкий отмечают взаимодействие сентименталистского и натуралистического дискурсов в современной «женской» прозе и в драматургии Н. Коляды [1. С. 84], Г.Л. Нефагина считает возможным говорить о сентименталистском реализме, в котором сентименталистские принципы «проявляются» через генетическую память «чужого» стиля, в результате чего происходит «мутация» реалистической структуры. По мнению исследователя, это «не синтез, то есть равноправное взаимодействие разных стилевых начал с качественным их изменением и рождением какогото нового стиля, но расширение стилевого спектра “традиционной” прозы» [13. С. 93]. К числу таких произведений Г.Л. Нефагина относит, в частности, повести «Здравствуй, князь!» А. Варламова, «Усыпальница без праха. Записки сентиментального созерцателя» Л. Бежина, «Сонечка» Л. Улицкой.

В дальнейшем, обращаясь к произведениям М. Шишкина и Е. Водолазкина, нам предстоит выяснить характер взаимодействия сентименталистских и постмодернистских дискурсных стратегий, проследить, как мутируют «чувствительность» и «чувствительный герой», как проявляют себя элементы сентиментализма в пространственно-временной организации, в специфике композиционных и жанровых решений, как они выражаются через сквозные мотивы.

Романы М. Шишкина и Е. Водолазкина убеждают в правомерности выделения и такой черты сентименталистской поэтики, которую Бахтин определил как «возвеличение... жизненной детали, мелочи, подробности» 
[9. С. 304]. Напомним, что философская основа сентиментализма - сенсуализм, согласно которому «источником и основанием знания является чувственность, данные органов чувств, чувственный опыт» [14]. И хотя сенсуализм воспринимается сегодня лишь как этап в истории науки и культуры XVIII в., видимо, не случайно к его опыту философская мысль периодически возвращалась и в XIX, и в начале XX в. Согласно нашей гипотезе реабилитация сенсорности в прозе М. Шишкина и Е. Водолазкина есть выражение потребности в преодолении абсурда бытия с помощью чувственного опыта, стремления противопоставить симулятивности реальности «первичные ощущения».

На наш взгляд, об актуализации в последнее время характерного для сентиментализма субъективного подхода к миру и человеку свидетельствует и тот факт, что писатели все чаще проявляют интерес к формам эпистолярия, дневника, к различным видам я-повествования. Примерами тому могут служить и романы «Письмовник» и «Авиатор», ставшие замет-

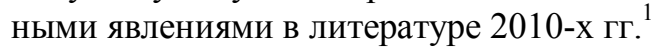

\section{2. Слово, «проникнутое тоном, смехом и слезами»}

В произведениях М. Шишкина и Е. Водолазкина интимная жизнь, частное бытие противопоставлены большой Истории как истинное - мнимому, «ненастоящему». Точкой отсчета в них являются гуманистические ценности, эмоциональная культура. При воссоздании «малого мира» и в том и в другом романах важную роль играют первичные физиологические ощущения - обоняние, осязание, зрение, слух, вкус. Героиня «Письмовника» прямо называет себя человеком «всего, что можно потрогать. И понюхать» [15. С. 15-16]. Отсюда - укрупнение чувственных ощущений, подробностей, деталей, которые выполняют роль «кирпичиков» в строительстве романного мироздания. В «Письмовнике» и «Авиаторе» это в значительной степени связано с мотивом детства / детскости, играющим важную роль и в том и в другом романах, что позволяет вспомнить открытый сентименталистами тип «человека естественного». Однако в произведениях Шишкина и Водолазкина представлены новые версии «чувствительного героя». М. Эпштейн еще в 1990-е гг. писал о том, как изменится «чувствительность XXI века»: «...она не будет разделять мир на трогательное и ужасное, милое и отвратительное. Она вберет в себя множество противочувствий. $<\ldots>$ Можно будет чувствовать все и по-всякому, вживаться в чувственность каждого предмета и смешивать ее с чувствами от других предметов» [3. С. 432]. Стилистика «Письмовника» и «Авиатора» основана именно на таких «противочувствиях». Подобного рода «чувствительность» не исключает и литературной игры. Поскольку герои Шишкина и Водолазкина смотрят на мир сквозь призму культуры, тексты строятся на игре цитат, реминисценций, аллюзий.

\footnotetext{
1 «Письмовник» и «Авиатор» вызвали большой интерес литературоведов и критиков (см.: $[8,16-21])$, но интересующий нас аспект еще не становился предметом изучения.
} 
Но эта игра не самоценна, в конечном итоге слово героев служит выражению гуманистического сознания, родственного авторскому.

\section{1. Сентименталистский «ключ» к постмодернистскому роману: «Письмовник» М. Шишкина}

«Письмовник» представляет собой переписку влюбленных, что уже предполагает обостренность чувств. Не случайно первое письмо героини содержит отсылку к программному произведению французского сентиментализма - лирико-философскому роману Ж.Ж. Руссо «Юлия, или Новая Элоиза»:

«И что же это получается? Юлия-дурочка старается, шлет ему письма, а жестокосердный Сен-Пре отделывается короткими шутливыми посланиями, иногда в стихах, рифмуя селедок и шведок, амуницию и сублимацию, засранное очко и улыбку Джоконды (кстати, ты понял, чему она улыбается? - я, кажется, поняла), пупок и Бог» [15. С. 3].

Следует заметить, что основная тональность этого диалога с сентиментализмом грустно-ироническая. «Рифмование» «засранного очка и улыбки Джоконды», «пупка и Бога» оказывается возможным потому, что сентименталистский дискурс проявляется в данном случае через постмодернистский. Это влечет за собой сдвиг «архетипических моделей» со своих «привычных гнезд», что сказывается и на исходной сюжетной ситуации. Если драма героев сентименталистских романов зачастую обусловлена тем, что влюбленных разделяет социальная пропасть, то здесь причина их разлуки совершенно иная - это пространство (Володя уходит на войну, а Сашенька ждет его дома) и время (разлучившись, они перемещаются в разные временные измерения). Таким образом, сами законы природы мешают им соединиться. Герои существуют лишь в текстовом пространстве писем. Тем не менее их ценностные ориентиры вполне отчетливы и определены с самого начала. Об этом свидетельствует уже первое письмо Володи, в котором представлена почти сентименталистская (по её конечному выводу) «дидактическая ситуация»:

На медкомиссии военврач - огромный череп лыс, шишковат - внимательно посмотрел в глаза. Сказал:

- Ты всех презираешь. Знаешь, я ведь тоже был таким. Мне было столько же, сколько тебе, когда я проходил первую практику в больнице. И вот нам однажды привезли бомжа, которого сбила машина. Еще жил, но уж очень сильно его изувечило. Особенно и не старались. Видно, что никому старик не нужен и никто за ним не придет. Вонь, грязь, вши, гной. В общем, положили в сторонку, чтобы ничего не испачкал. Сам дойдет. А я должен был потом убрать, помыть и отправить тело в морг. Все ушли, оставили меня одного. Я вышел покурить и думаю - зачем мне все это надо? Кто мне этот старик? Зачем он нужен? Пока курил, тот дошел. И вот вытираю кровь, гной - кое-как, чтобы поскорее его отправить в морозилку. И тут подумал, что, может, он кому-то отец. Принес тазик с горячей водой, 
стал его обмывать. Тело старое, заброшенное, жалкое. Никто его годами не гладил. И вот я мою его ноги, страшные скрюченные пальцы, а ногтей почти и нет - все съел грибок. Протираю губкой все его раны, шрамы - и тихо с ним разговариваю: ну что, отец, тяжелая у тебя получилась жизнь? Нелегко, когда тебя никто не любит. Да и как это в твоем-то возрасте жить на улице бездомной собакой? Но теперь-то все закончилось. Отдохни! Теперь все хорошо. Ничего не болит, никто не гонит. И вот так мыл его и разговаривал. Не знаю, помогло ли это ему в смерти, но мне это очень помогло жить [15. С. 10]

По словам М.М. Бахтина, сентименталистская дидактика «...становится конкретной, углубляющейся в самые детали быта, интимных отношений между людьми и внутренней жизни личности» [22. С. 208]. Н. Лейдерман и М. Липовецкий обнаруживают аналогичную тенденцию в женской прозе 1990-х, в том, как трактуется в ней тема маленького человека: «...эта литература окружает его состраданием и жалостью, но сам герой сентиментального натурализма еще не готов к самосознанию, он целиком замкнут в эмоционально-физиологической сфере» [1. С. 84]. В романе «Письмовник» другой тип героя и, соответственно, другая ситуация. Володя не замкнут в «эмоционально-физиологической сфере» и готов к самосознанию, тем не менее именно через приобщение к физиологической сфере он начинает сознавать ценность сострадания и жалости. Такие уроки человеколюбия помогают ему жить.

Шишкин прослеживает этапы «воспитания чувств», процесс самопознания личности. Но этот путь проходит герой эпохи постмодерна, в связи с этим примечательно, что Володя идет не от простого к сложному, а наоборот: он отправляется на войну, чтобы «научиться понимать простые вещи» [15. С. 13]. В результате герой осознает, что чем больше зла вокруг, тем важнее «сохранить в себе крупицы человечности» [Там же. С. 283]. Главным источником и основным критерием человечности для него является любовь. При этом характерно, что даже самые интимные переживания Володя выражает с помощью цитат, аллюзий, реминисценций. И все же постепенно постмодернистский цитатный дискурс подчиняется сентименталистскому - чувственному. Так, в одном из посланий Сашеньке Володя пишет:

Помню, читаю в Гамлете: «Распалась связь времен». Знаешь, о чем на самом деле писал Шекспир? О том, что эта связь восстановится, когда мы снова встретимся и я положу тебе голову на колени [Там же. С. 359].

Именно через такие «простые вещи», как любовь, герой заново открывает для себя ценности культуры, сознает, от чего зависит «связь времен». Эта мысль определяет и авторскую концепцию произведения, его сюжетно-композиционную структуру и сам характер повествования.

Для героев «Письмовника» реален лишь мир их чувств, лишь то, что напоминает им об их любви. К этой субъективной реальности применимы те характеристики, которые Бахтин дает идиллическому хронотопу. Обо- 
значая черты идиллии, ученый называет, прежде всего, «органическую прикрепленность, приращенность жизни и ее событий к месту - к родной стране со всеми ее уголками. Пространственный мирок этот ограничен и довлеет себе, не связан существенно с другими местами, с остальным миром... Другая особенность идиллии - строгая ограниченность ее только основными немногочисленными реальностями жизни. Они сближены между собой и равнодостойны (...)» [22. С. 374]. И третья особенность «сочетание человеческой жизни с жизнью природы, единство их ритма...» [Там же]. Горькая ирония романа Шишкина заключается в том, что единственным местом, где возможна идиллия, оказывается текст.

Идиллический мир воссоздается в воспоминаниях влюбленных о том единственном лете, когда они были вместе, он ограничен теми местами, где они были счастливы. Недаром мотив счастья пронизывает весь роман. Сашенька называет себя «жадной до счастья» [15. С. 12]. Володя даже среди ужасов войны способен чувствовать себя счастливым, потому что понимает: «...все это кругом - ненастоящее», а настоящее лишь то, что было тем летом на даче: «...это как я зашел помыть руки в ванную, а там увидел твою губку и так остро почувствовал, что она касалась твоей груди» [Там же]. Главный вывод, к которому он приходит, оказавшись на войне, заключается в том, что «мир - это не сон, и я - это не иллюзия. Я - существует, и нужно сделать его счастливым» [Там же. С. 303].

В романе у идиллического мира есть своя топография, свои дорогие героям «немногочисленные реальности жизни» [22. С. 374], о которых они рассказывают в своих письмах. Как говорит Саша, «для счастья нужны свидетели. По-настоящему можно чувствовать себя счастливым, только получив какое-то подтверждение» [15. С. 18]. Для влюбленных такими «свидетелями» становятся самые простые бытовые вещи: их зубные щетки, стоящие рядом в стакане, хранящие запах Володи подушка, рубашка, ботинки и т.п. Герои находят «свидетелей» счастья и в мире природы, в котором, как им кажется, все «рифмуется» с их любовью: «кареглазые коровы» и «козьи орешки на тропинке», «запруда», в которой «толстолобики бодаются с небом», и утренний след в росистой траве, ветер, который испытывал их и деревья «на парусность», и многое другое. «Эти рифмы связывают мир, сбивают его, как гвозди, загнанные по шляпки, чтобы он не рассыпался» [Там же. С. 12].

Но сюжет «Письмовника» связан с разрушением этой «текстовой идиллии». После известия о Володиной гибели жизнь Саши фактически тоже закончилась. Лишь возобновив переписку, начав отвечать на его старые письма, которые продолжали приходить и после трагического известия, она вновь обрела смысл существования. В результате хрупкий идиллический хронотоп вновь восстанавливается. Текст по-прежнему остается для героев единственной подлинной реальностью. В финале его границы, кажется, преодолеваются: влюбленные выходят за его пределы и отправляются к месту «общего схода», где «тела могут соприкасаться, и нет никакого зазора между душами» [Там же. С. 413]. Но этот «общий сход» ока- 
зывается возможен лишь за пределами жизни. И все же примечательно, что мир вечности представлен через интимные детали и подробности, которые являются для героев знаками памяти сердца. Собираясь в последнее путешествие, Володя берет с собой самое «важное» - предметы, запахи, звуки, ощущения, напоминающие ему о детстве, о любви, т.е. то, что вновь связано с чувственным опытом: треск «прутиком по решетке», стрекотание кузнечиков - «будто кто-то заводит часики», «сладкий дух из кондитерской», «план парохода в разрезе», который в детстве висел у него над кроватью, «лист из гербария, на котором написано старательным детским почерком: “Подорожник, Plantago"», колючки репейника, которые он бросал в волосы Саше, «мамино кольцо, которое еще только кружится по подоконнику», «обрывок газеты, приставший к порезу от бритья» [15. С. 411, 412] - как напоминание об отчиме и многое другое, позволяющее сохранить родственную связь между «внутренними людьми». Эти «важные» вещи вновь побуждают вспомнить слова Бахтина о составляющих идиллического хронотопа: «...они сближены между собой и равнодостойны...» [22. С. 374]. В этом мире, кажется, сохраняется и присущее идиллическому хронотопу «сочетание человеческой жизни с жизнью природы, единство их ритма...» [Там же]. Саша отправляется к месту «общего схода» вместе со своей дочкой-Снегурочкой. И хотя то, что она слепила её из снега, вновь напоминает, насколько эта идиллия хрупка и уязвима, но, пусть даже в таком - симулятивном - обличье, гармония восстанавливается, о чем свидетельствует и заключительный диалог Саши с дочкой:

- Послушай, я должна тебе что-то сказать. Там будет один человек, не удивляйся, он положит мне голову на колени.

- Почему? Он тебя любит?

- Да.

- Я тоже тебя люблю. Очень-очень!

И положила мне голову на колени [15. С. 409].

Таким образом, хаосу большого мира вновь противопоставляется Космос мира малого.

\section{2. "...Жизнь как тишина осенняя подробна»:}

Реабилитация сенсорности в романе Е. Водолазкина «Авиатор"

Е. Водолазкин в одном интервью сказал: «"Авиатор" - это роман о другой истории: истории чувств, фраз, запахов, звуков, которые по большому счету не менее важны, чем великие события. В каком-то смысле они определяют те события, которые входят в учебники, но при этом сами незаслуженно исчезают...» [23].

Эти слова можно истолковать в постмодернистском ключе: увидеть в них выражение принципа множественности истин, тотального плюрализма как следствия децентрализации, деконструкции. И хотя в романе Водолаз- 
кина, действительно, выражены приметы постмодернистской эстетики, которые обнаруживают себя и в особенностях композиции, и в насыщенности текста литературной игрой, в том числе с жанровыми моделями массовой литературы, постмодернистский дискурс в «Авиаторе» подчинен неосентименталистскому. Доказательству этой мысли и будет посвящен дальнейший анализ.

Книга Водолазкина написана в форме дневника, точнее, каждодневных записок, которые ведет главный герой Иннокентий Платонов. Во второй части романа такие записи, по его просьбе, также начинают вести близкие ему люди - доктор Гейгер и жена Иннокентия Анастасия. Так возникает трижды субъективная форма повествования. В романе дается следующее обоснование значимости этой субъективности:

Жизнь, реальность - на уровне человеческой души, там корни всего плохого и хорошего. Все решается прикосновением к душе [24. С. 344].

В «Авиаторе» своеобразие повествовательной формы определяется особым типом героя: дневник начинает вести человек, выключенный из общего потока жизни. Сюжетная ситуация в романе Водолазкина словно иллюстрирует тезис Бахтина об «экстерриториальности» как черте «человека сентиментализма»: «вне мира сего, вне жизненной колеи» [9. С. 304]. На это указывает и имя героя - Иннокентий, что в переводе с латинского означает «невинный». Он выпал из своего времени и почти фантастическим образом оказался в другом.

Во время своего пребывания в 1920-е гг. в Соловецком концлагере Платонов стал одним из участников медицинского эксперимента по искусственному замораживанию живого человеческого организма. Он оказался единственным из всех подопытных, кому удалось выжить. Ровесник XX в., Иннокентий пробуждается в 1990-е гг. и практически ничего не помнит ни о себе, ни о своих близких, ни о своем времени. Фантастический сюжетный ход, который использует Е. Водолазкин, многократно отработан как в «высокой», так и в «массовой литературе». Но постмодернистский прием «чужой тары» служит здесь выражению отнюдь не симулятивного содержания ${ }^{1}$.

\footnotetext{
${ }^{1}$ Михаил Визель начал интервью с Е. Водолазкиным с того, какие интертекстуальные пласты задействованы в его новом романе: «Когда я стал читать «"Авиатора", у меня стали в голове “выщелкиваться" один за другим маркеры: этот сюжетный ход герой мгновенно теряет и медленно восстанавливает память - из Эко, из "Волшебного пламени царицы Лоаны”; этот - “воскрешение" в иной эпохе - из “Когда спящий проснётся” Герберта Уэллса; накладывающиеся друг на друга дневники, в которых поразному излагаются одни и те же события, - “Лунный камень” Уилки Коллинза; а ключевой мотив "тогда было так, а теперь эдак, причем гораздо хуже" - вообще можно вывести из "Потока-богатыря" Алексея Толстого. В общем, постмодернистская конструкция, переполненная явными и скрытыми цитатами и аллюзиями. Это было сделано сознательно, или это моя читательская “гиперинтерпретация”?». На что писатель ответил: «У меня есть слабость: я люблю работать с жанровой литературой. По крайней
} 
Роман строится на взаимодействии разных дискурсных стратегий: постмодернистской, реалистической и сентименталистской. С определенной долей условности можно сказать, что постмодернистский дискурс в основном проявляет себя в «современных» главах (герой оказался в мире масскульта, где реальность вытесняется подделками, трагедия заменяется фарсом), а реалистический - в главах о прошлом Платонова, в том числе о Соловецком лагере, где автор следует принципам объективности, психологической достоверности. Сентименталистский дискурс, вступая во взаимодействие с тем и с другим, служит альтернативой и симулятивности реальности и натуралистическому реализму. С ним связаны ключевые ценностные ориентиры, авторская концепция времени, жанровая стратегия.

Платонов начинает вести дневник, чтобы восстановить связь между прошлым и настоящим. Примечательно, что его записи не имеют датировки, они обозначаются по дням недели, затем их заменяют имена героев, от лица которых они ведутся, а в конце и эти различия исчезают. В романе дается следующее объяснение подобной форме повествования:

...календарные даты принадлежат к линейному времени, а дни недели к циклическому.

Линейное время - историческое, а циклическое замкнуто на себе. Вовсе и не время даже.

Можно сказать вечность [24. С. 229].

В результате история, излагаемая тремя героями, «никуда не стремится», но именно поэтому она и есть «самая надежная» [Там же].

Своеобразие мировосприятия Платонова связано с тремя ключевыми архетипическими образами - это Авиатор, Адам и Робинзон Крузо. Роль первого определяется заглавием произведения и его эпиграфом, в котором авиатором назван «тот, чей обзор достаточно широк» [Там же]. Это может быть и сам автор, и его герой, которому принадлежит данное определение. В качестве эпиграфа Водолазкин использует диалогический фрагмент из финального эпизода романа - разговор Платонова со священником, который происходит в самолете, незадолго до его крушения. Именно здесь герой объясняет смысл своих дневниковых записей, которые он продолжает вести даже после того, как понимает, что всем пассажирам грозит гибель. Иннокентий описывает «предметы, ощущения», людей, «надеясь спасти их от забвения» [Там же. С. 409]. Такое объяснение позволяет предположить, что «тот, чей обзор достаточно широк» - иносказательное обозначение Бога-творца, с той существенной поправкой, что речь идет о слове, зафиксированном на бумаге. Причем с его помощью герой даже не просто тво-

мере, начинать в одном из ее жанров, а затем - покидать его границы. Я беру исторический роман - и делаю неисторический. Беру жанр фантастики - и пишу то, что к фантастике не имеет ровно никакого отношения. Что до литературных прецедентов, то их множество... мне кажется, легче перечислить тех, у кого нет этого сюжета, чем тех, у кого он присутствует. Но я наполняю его совершенно другим содержанием» [23]. 
рит свой мир, но надеется его спасти. При этом субъективные ощущения и чувства обретают статус объективных, а потому именно они становятся в романе основой авторского миромоделирования. Как и в «Письмовнике», в «Авиаторе» как будто актуализируются идеи сенсуализма, согласно которым основным способом познания является субъективный опыт. Очевидно, это продиктовано глубоким разочарованием в больших проектах по переустройству мира, недоверием к опыту творцов истории. Не случайно, объясняя Гейгеру и Анастасии, какими должны быть их описания, Платонов подчеркивает, что они «должны касаться чего-то такого, что не занимает места в истории, но остается в сердце навсегда» [24. С. 336]. Из них, по его замыслу, подобно мозаике, должна сложиться наиболее объективная картина жизни. Её создание подчиняется закону обратной перспективы: в описаниях рассказывается не о больших событиях эпохи, будь то история или культура, а о тех вещах, «которые переживаются и вспоминаются одинаково», таких, например, как «шум дождя, ночной шелест листьев», словом, то, что объединяет, а не разъединяет людей. Платонов убежден, что этот частный опыт и есть «всему основа» [Там же. С. 348]. Он убедился в этом на собственном примере: «...его формировали не побои в лагере. Совсем другие вещи. Например, стрекотание кузнечиков в Сиверской. Запах вскипевшего самовара», потому что «и тот, и другой распространяют спокойствие и мир», в этом и заключается «их исторический смысл» [Там же]. Такие «фундаментальные события», как, к примеру, «питье чая на веранде», «способны определять совершенно разные времена, а значит - универсальны» [Там же. С. 365], в них заключается связующая нить вечности. Вот почему «Ватерлоо забудется, в то время как хорошая беседа - никогда» [Там же. С. 381].

В вынесенном в эпиграф высказывании героя о том, что своими описаниями он надеется спасти вещи и людей от забвения, важен и глагол «надеяться». Не знание, не разум, не воля и целеполагание, а надежда становится импульсом к действию. Здесь вновь уместно вспомнить прогноз Н. Лейдермана о том, какой может стать в новую «культурную эпоху» идея Космоса: «...это будет Космос, знающий о своей хрупкости, необъективности и условности, Космос, не забывающий о соседстве с Хаосом, не отделяющий себя от Хаоса и ведущий с ним не прекращающийся ни на секунду философский диалог» [2].

Герой «Авиатора» оказывается одновременно в ситуации Адама (он сознает себя единственным человеком своего времени) и в ситуации Робинзона, который вынужден осваивать «новую землю», учиться жить в совершенно новых условиях. Обе эти архетипические ситуации объединяет детский дискурс. Установление связи прошлого с настоящим начинается у Платонова с воспоминаний детства. Он признается, что чувствует «себя Адамом. Или ребенком...» [24. С. 22]. Образ Робинзона тоже соотносится с воспоминаниями о доме, о милых сердцу подробностях, которые хранит детская память. Иннокентий вспоминает, как бабушка читала ему «Робинзона Крузо»: 
Я слежу за бабушкиными губами. Перед тем, как перевернуть страницу, она подносит к губам палец. Иногда прихлебывает остывший чай, и тогда на "Робинзона Крузо" летят едва заметные брызги. Иногда - крошки от съеденного между главами сухаря. Выздоровев, я внимательно перелистываю прочитанное и вытряхиваю хлебные частицы, высохшие и сплющенные [24. С. 16].

Книга Дефо становится для Платонова способом обретения почвы под ногами. Как и герой его любимой книжки, Иннокентий чувствует себя «в другом времени - с прежним опытом, прежними привычками, ему нужно или их забыть, либо воссоздать весь утраченный мир, что очень непросто» [Там же. С. 42]. Вот почему преобразование Хаоса в Космос начинается именно с этой книги. Он просит медсестру почитать ему «Робинзона Крузо», которого помнит почти наизусть. В романе «Авиатор» упоминания о Робинзоне встречаются не менее 20 раз. Но мотив робинзонады у Водолазкина наполняется новым смыслом. Используя аналогичный сюжетный ход и близкую роману Дефо форму я-повествования, писатель интерпретирует образ Робинзона по-своему. Дефо создал тип «homo economicus», человека здравого смысла и сильной воли, свободного от сентиментальности, а герой Водолазкина называет его «бедным» [Там же. С. 290]. В романе «Авиатор» выражено состояние человека, которому приходится начинать жизнь с чистого листа. Платонов ищет нравственные ориентиры, те ценности, которые помогли бы ему выжить в новом мире. Это побуждает его обратиться к детству. Его дневник отражает поиск дороги «домой». Книга Дефо воспринимается героем как знак, указывающий ему путь, это то немногое, что связывает его с детством.

Но в романе «Авиатор» у «Робинзона» появляется сопутствующий мотив - «блудного сына» [Там же. С. 16, 316]. В своих размышлениях Платонов постоянно возвращается к теме суда совести. Не случайно образ Фемиды сопровождает его на протяжении всей жизни. Путь героя представлен как трудный процесс изживания вины, духовного очищения (он убил человека, написавшего донос на отца его возлюбленной). Отсюда значимость еще одного библейского подтекста - притчи о воскрешении Лазаря. В романе эта параллель обретает прямой, горько-иронический смысл: лаборатория на Соловках, где проводили опыты над людьми, обозначалась аббревиатурой ЛАЗАРЬ, т.е. «лаборатория по замораживанию и регенерации», поэтому подопытных здесь называли лазарями [Там же. С. 207]. В основе сюжета романа - в прямом смысле воскрешение «лазаря». Но более важен иносказательный смысл этого подтекста, выраженный через диалогическую связь не столько с библейской притчей о Лазаре четверодневном, сколько с романом Достоевского «Преступление и наказание»: речь идет о духовном воскрешении, которое предполагает раскаяние и прощение. Внутренние изменения, которые происходят в герое, наглядно проявляются в его отношении к доносчику Зарецкому. Вначале Платонов видел в нем недочеловека, «мокрицу», вызывающую лишь отвращение. 
Неудивительно, что, решив его убить, он не испытывал мук совести. Однако постепенно в его глазах Зарецкий превращается в фигуру, вызывающую сострадание и жалость.

Мотив прощения охватывает в романе целый ряд «преступников»: помимо доносчика Зарецкого, это и кузен Иннокентия Сева, обрекший его на пребывание в лагере на Соловках, где он должен был погибнуть, и лагерный «людоед» гэпэушник Воронин, о котором говорится, что «нет таких злодеяний, каких бы он не совершил» [24. С. 354]. Никто из них не осознал своей вины. И все-таки Платонов прощает их. Раскаяние научило его милосердию, пониманию другого, состраданию. Он приходит к выводу, что «потеря всякого человека и всякой вещи является частью смерти. Которая есть потеря всего» [Там же. С. 313]. Поэтому на вопрос, что выше справедливости, он вначале отвечает - «милосердие», а потом дает новый ответ «любовь» [Там же].

Романы «Письмовник» и «Авиатор» говорят с читателем на языке чувств. Их героями руководит «всесильный бог деталей, всесильный бог любви». Сентиментальность проявляется в этих произведениях в авторской концепции времени, в утверждении ценности частного существования, в типах героев, в сквозных мотивах, в повествовательной стратегии, в звучании романного слова. Вот почему, на наш взгляд, в данном случае можно говорить и о «новой сентиментальности», определяющей критерии оценок, и неосентименталистском дискурсе как доминанте повествовательной структуры, и о «новом сентиментализме» как эстетическом феномене. Все это позволяет воспринимать романы М. Шишкина и Е. Водолазкина как произведения, указывающие возможный вектор развития современной интеллектуальной прозы.

\section{Лuтература}

1.Лейдерман Н., Липовецкий М. Современная русская литература : в 3 кн. Кн. 3: В конце века (1986-1900-е годы). М. : Эдиториал УРСС, 2001. 160 с.

2. Лейдерман $H$. Траектории «экспериментирующей эпохи». URL: http://voplit.ru/eText/2002/2002-4/2002-4/2002-4.html\#5 (дата обращения 17.03.2018).

3. Эпштейн М.Н. Постмодерн в русской литературе : учеб пособие для вузов. М. : Высш. шк., 2005. 495 с.

4. Stearns P.N., Stearns CZ. Emotionology: Clarifying the His-tory of Emotions and Emotional Standards // The American Historical Review. 1985. Vol. 90, № 4. P. 813-836.

5. Российская империя чувств: Подходы к культурной истории эмоций / под ред. Я. Плампера, Ш. Шахадат, М. Эли. М. : НЛО, 2010. 512 с.

6. Rosenwein B.H. Problems and Methods in the History of Emotions // Passions in Context: International Journal for the History and Theory of Emotions. 2010. № 1. URL: https://www.passionsincontext.de/index.php/?id=557 (дата обращения: 05.03.2018).

7. Винницкий И. Заговор чувств, или Русская история на «эмоциональном повороте» // НЛО. 2012. № 117. URL: http://magazines.russ.ru/nlo/2012/117/v35.html (дата обращения: 05.03.2018).

8. Рогова Е. Некоторые аспекты художественной целостности романа М. Шишкина «Письмовник» // Вестник Томского государственного университета. Филология. 2014. № 5 (31). URL: http://journals.tsu.ru/philology/en/\&journal_page=archive\&id=1091 \&article_id=30748 (дата обращения: 10.03.2018). 
9. Бахтин М.М. Собрание сочинений : в 7 т. М. : Русские словари, 1997. Т. 5. C. $304-305,614$.

10. Карамзин H. Что нужно автору? URL: http:/dugward.ru/library/karamzin/karamzin_chto_nujno.html (дата обращения: 09.03. 018).

11. Пашкуров А.Н., Разживин А.И. История русской литературы XVIII века : в 2 ч. М.: Флинта, 2017. Ч. 2. 525 с.

12. Кожевников М.B. Английская сентиментальная комедия в системе драматических жанров. Магнитогорск, 2001.

13. Нефагина Г.Л. Русская проза конца ХХ века. М. : Флинта : Наука, 2003. 320 с.

14. Кузнеиов М.Ф. Сенсуализм // Словарь философских терминов / науч. ред. В.Г. Кузнецова. М. : ИНФРА-М, 2007. С. 490. URL: http://www.rfp.psu.ru/archive/ 3.2013/bochkareva.pdfhttp://ponjatija.ru/node/733 (дата обращения: 05.03.2018).

15. Шиикин М. Письмовник. М. : АСТ : Астрель, 2010. 412 с.

16. Лашова С. Поэтика Михаила Шишкина: система мотивов и повествовательные стратегии : автореф. дис. ... канд. филол. наук. Пермь, 2012. 20 с.

17. Гримова О. Роман М. Шишкина «Письмовник»: стратегии нелинейности. URL: http://gigabaza.ru/doc/25331.html (дата обращения: 01.03.2018).

18. Прохорова Т.Г. Система хронотопов в романе Михаила Шишкина «Письмовник»: к проблеме художественной целостности // Изв. Саратов. ун-та. Нов. сер. Сер. Филология. Журналистика 2016. Т. 16, вып. 4. С. 447-451.

19. Солдаткина Я.В. Мотивы прозы А.П. Платонова в романе Е.Г. Водолазкина «Авиатор» // Rhema. Рема. 2016. № 3. C. 19-28. URL: http://rhema-journal.com/Rema-32016.pdf (дата обращения: 12.03. 2018).

20. Бочкина М.В. Отражение средневековой концепции времени в романах Е. Водолазкина «Лавр» и «Авиатор» // Вестник РУДН. Серия: Литературоведение. Журналистика. 2017. Vol. 22, № 3. C. 475-483. URL: file:///C:/Users/User/Downloads/17087-176091-PB.pdf (дата обращения: 12.03.2018).

21. Москвина T. Трагедия размороженного интеллигента. URL: http://argumenti.ru/ culture/n550/461775 (дата обращения: 14.03.2018).

22. Бахтин М.M. Вопросы литературы и эстетики:. Исследования разных лет. М. : Худ. лит., 1975. URL: http://biblio.imli.ru/images/abook/teoriya/ Bahtin_M.M._Voprosy_ literatury i estetiki 1975.pdf (дата обращения: 12.03.2018).

23. Визель М. Йнтервью с Евгением Водолазкиным. URL: https://godliteratury.ru/publicpost/aviator-vodolazkin-intervyu (дата обращения: 12.03.2018).

24. Водолазкин Е. Авиатор. М. : АСТ : Редакция Елены Шубиной, 2016. 410 с.

\section{"New Sentimentality" in the Novels Pismovnik by Mikhail Shishkin and The Aviator by Eugene Vodolazkin \\ Vestnik Tomskogo gosudarstvennogo universiteta. Filologiya - Tomsk State University Journal of Philology. 2019. 59. 216-232. DOI: 10.17223/19986645/59/13 \\ Tatiana G. Prokhorova, Kazan (Volga Region) Federal University (Kazan, Russian Federation). E-mail: tatprohororova@yandex.ru}

Keywords: new sentimentality, sensitivity, sensuality, epistolary novel, diary, sentimentalist discourse, M. Shishkin, E. Vodolazkin.

The essay explores the phenomenon of "new sentimentality", the nature of functioning and forms of manifestation of sentimentalist discourse in the novels Pismovnik [Letter-Book] by Mikhail Shishkin and The Aviator by Eugene Vodolazkin. The essay consists of two paragraphs. The theoretical synopsis provides the background for the analysis of the mentioned works of the 2010s, which demonstrate one of the most promising trends in the development of the latest prose related to the experience of sentimentalism. Since a direct inheritance of sentimentalist traditions in the literature of the 21 st century is impossible, the dialogue with it is carried out according to the law of negation of the negation or the 
oxymoronic principle, which allows to combine the incongruous. But changing and transforming the "new sentimentality" still does not lose the connection with the "primary source".

In the course of the analysis it is proved that in Shishkin's and Vodolazkin's novels the dialogue with sentimentalism is manifested not only at the level of the characters' world perception but also at the level of the author's concept, which determines the system of values, the specifics of the genre and the form of the narrative, the nature of the leitmotivs and the peculiarities of the plot structure. In Pismovnik, the sentimental discourse interacts with the postmodern one, in The Aviator with the postmodern and realistic discourses. However, being integrated into a "foreign" system, it remains relatively independent and retains its aesthetics. "New sentimentality" in Shishkin's and Vodolazkin's novels is a form of rehabilitation of humanistic values, assertion of the significance of the "small" world, as opposed to the "big" one, counter to the postmodern world as text, the cruelty of reality and the simulative world of mass culture.

An important role in recreating the "small world" in Pismovnik and The Aviator is played by primary physiological sensations - sense of smell, touch, vision, hearing, taste. It is closely connected with the motive of childhood, which is very important in both novels and allows to recall the open sentimentalists' type of a "natural man". However, in the works of Shishkin and Vodolazkin, new versions of a "sensitive hero" is presented. He perceives the world through the prism of culture, so the texts are based on the game with quotes, remarks, allusions. But this game is not self-valuable: at the end of the analyzed novels the word of the characters serves as an expression of a humanistic consciousness related to the author.

The author of the article comes to the conclusion that in relation to the novels Pismovnik by Shishkin and The Aviator by Vodolazkin we can talk about "new sentimentality", which determines evaluation criteria, about neo-sentimentalist discourse as the dominant element of the narrative structure and about "new sentimentalism" as an aesthetic phenomenon. All this makes it possible to perceive these works as a symptomatic phenomenon indicating a possible vector of development of modern intellectual prose.

\section{References}

1. Leyderman, N. \& Lipovetskiy, M. (2001) Sovremennaya russkaya literatura: $v 3 \mathrm{kn}$. [Modern Russian literature: in 3 books]. Book 3. Moscow: Editorial URSS.

2. Leyderman, N. (2002) Traektorii "eksperimentiruyushchey epokhi" [Trajectories of the "Experimental Epoch"]. Voprosy literatury. 4. [Online] Available from: http://voplit.ru/eText/ 2002/2002-4/2002-4/2002-4.html\#5. (Accessed 17.03.2018).

3. Epshteyn, M.N. (2005) Postmodern v russkoy literature [Postmodern in Russian literature]. Moscow: Vyssh. shk.

4. Stearns, P.N. \& Stearns, C.Z. (1985) Emotionology: Clarifying the History of Emotions and Emotional Standards. The American Historical Review. 90 (4). pp. 813-836.

5. Plamper, J., Schahadat, S. \& Elie, M. (eds) (2010) Rossiyskaya imperiya chuvstv: Podkhody k kul'turnoy istorii emotsiy [In the Realm of Russian Feelings: Approaches to the Cultural History of Emotions]. Moscow: NLO.

6. Rosenwein, B.H. (2010) Problems and Methods in the History of Emotions. Passions in Context: International Journal for the History and Theory of Emotions. 1. [Online] Available from: https://www.passionsincontext.de/index.php/?id=557. (Accessed: 05.03.2018).

7. Vinnitskiy, I. (2012) Zagovor chuvstv, ili Russkaya istoriya na "emotsional'nom povorote" [Conspiracy of feelings, or Russian history at the "emotional turn"]. NLO - New Literary Observer. 117. [Online] Available from: http://magazines.russ.ru/nlo/ 2012/117/v35.html. (Accessed: 05.03.2018).

8. Rogova, E. (2014) Some aspects of the artistic integrity of M. Shishkin's novel Pismovnik. Vestnik Tomskogo gosudarstvennogo universiteta. Filologiya - Tomsk State University Journal of Philology. 5 (31). pp. 105-118. [Online] Available from: 
http://journals.tsu.ru/philology/en/\&journal_page=archive\&id=1091\&article_id=30748. (Accessed: 10.03.2018). (In Russian). DOI: 10.17223/19986645/31/8

9. Bakhtin, M.M. (1997) Sobranie sochineniy: $v 7 t$. [Collected Works: In 7 vols]. Vol. 5. Moscow: Russkie slovari. pp. 304-305, 614.

10. Karamzin, N. (1794) Chto nuzhno avtoru? [What does the author need?]. [Online] Available from: http://dugward.ru/library/karamzin/karamzin_chto_nujno.html. (Accessed: 09.03. 018).

11. Pashkurov, A.N. \& Razzhivin, A.I. (2017) Istoriya russkoy literatury XVIII veka: v $2 \mathrm{ch}$. [The history of Russian literature of the 18th century: in 2 parts]. Pt. 2. Moscow: Flinta.

12. Kozhevnikov, M.V. (2001) Angliyskaya sentimental'naya komediya $v$ sisteme dramaticheskikh zhanrov [English sentimental comedy in the system of dramatic genres]. Magnitogorsk: Magnitogorsk State University.

13. Nefagina, G.L. (2003) Russkaya proza kontsa XX veka [Russian prose of the end of the 20th century]. Moscow: Flinta: Nauka.

14. Kuznetsov, M.F. (2007) Sensualizm [Sensualism]. In: Kuznetsova, V.G. (ed.) Slovar' filosofskikh terminov [Dictionary of philosophical terms]. Moscow: INFRA-M. [Online] Available from: http://www.rfp.psu.ru/archive/ 3.2013/bochkareva.pdfhttp://ponjatija.ru/ node/733. (Accessed: 05.03.2018).

15. Shishkin, M. (2010) Pis 'movnik [Letter-Book]. Moscow: AST: Astrel'.

16. Lashova, S. (2012) Poetika Mikhaila Shishkina: sistema motivov i povestvovatel'nye strategii [Poetics of Mikhail Shishkin: A system of motives and narrative strategies]. Abstract of Philology Cand. Diss. Perm.

17. Grimova, O. (n.d.) Roman M. Shishkina "Pis'movnik": strategii nelineynosti [M. Shishkin's novel "Pismovnik": nonlinearity strategies]. [Online] Available from: http://gigabaza.ru/doc/25331.html. (Accessed: 01.03.2018).

18. Prokhorova, T.G. (2016) A System of Chronotopes in Mikhail Shishkin's Novel Pismovnik (Letter Book): on the Issue of Artistic Unity. Izv. Saratov. un-ta. Nov. ser. Ser. Filologiya. Zhurnalistika - News of Saratov University. New Series. Ser. Studies of Language and Literature. Journalism. 16 (4). pp. 447-451. (In Russian). DOI: 10.18500/1817-71152016-16-4-447-451

19. Soldatkina, Ya.V. (2016) The motives of A.P. Platonov's prose in the novel "Aviator" by E.G. Vodolazkin. Rhema. Rema. 3. pp. 19-28. (In Russian). [Online] Available from:http://rhema-journal.com/Rema-3-2016.pdf. (Accessed: 12.03. 2018).

20. Bochkina, M.V. (2017) Medieval concept of time reflection in E. Vodolazkin's novels "Laurus" and "The Aviator". Vestnik RUDN. Seriya: Literaturovedenie. Zhurnalistika RUDN Journal of Studies in Literature and Journalism. 22 (3). pp. 475-483. (In Russian). DOI: $10.22363 / 2312-9220-2017-22-3-475-483$

21. Moskvina, T. (2016) Tragediya razmorozhennogo intelligenta [Tragedy of an unfrozen intellectual]. [Online] Available from: http://argumenti.ru/culture/n550/461775. (Accessed: 14.03.2018).

22. Bakhtin, M.M. (1975) Voprosy literatury $i$ estetiki: Issledovaniya raznykh let [Questions of literature and aesthetics: Studies of different years]. Moscow: Khud. lit. [Online] Available from: http://biblio.imli.ru/images/abook/teoriya/Bahtin_M.M._Voprosy_literatury_ i_estetiki_1975.pdf. (Accessed: 12.03.2018).

23. Vizel', M. (2016) Interv'yu s Evgeniem Vodolazkinym [Interview with Eugene Vodolazkin]. [Online] Available from: https://godliteratury.ru/public-post/aviator-vodolazkinintervyu. (Accessed: 12.03.2018).

24. Vodolazkin, E. (2016) Aviator [The Aviator]. Moscow: AST: Redaktsiya Eleny Shubinoy. 